\title{
Moral Literacy and Social Climate with Perception Teacher's Character Education in Elementary School
}

\author{
Prayuningtyas Angger Wardhani, Zulela M S, Reza Rachmadtullah, Yulia Elfrida Yanty Siregar \\ Department of Elementary Education \\ State University of Jakarta \\ Jakarta, Indonesia \\ prayuningtyasangger@gmail.com
}

\begin{abstract}
The aim of this research is to know the effect of moral literacy and social climate with teachers perception on character education in elementary school, the number of teacher is 145 teacher. The technique used to analyze data is statistical regression technique with correlational method. The results showed that there is a positive influence between (1) moral literacy with teachers perception on character education in elementary school (2) social climate with teachers perception toward character education in elementary school (3) moral literacy and social climate with teachers perception on character education in elementary School. It could be concluded that research, there is influence of moral literacy and social climate with teachers perception on character education in elementary school.
\end{abstract}

Keywords - moral literacy; social climate; teachers perception of character education

\section{INTRODUCTION}

Good teaching requires a knowledgeable, skilled and virtuous method of disposition and character. Teachers need to have knowledge not only in subjects but also in moral theory and processes related to character development. Teachers have a serious role as a moral agent, they must be able to understand the change in the development of reasoning morality. Teachers should be able to understand the moral problems of something else, such as social conventions. Education begins to emphasize morals in teaching dimensions. If the teaching should be viewed as a reflective moral act, then the teacher as an education moral agent needs to provide a basic theory of moral literacy. Lack of teacher preparation in providing moral / character education to a concern [1].

Schools are considered as a place to embed character education apart from home. Teachers are agents of moral cultivation at school. For Bandura [2], agents are people who act on purpose to make things happen on behalf of others. Moral agents are also bound to do what is right, to pursue a good, to be very well-ethical, and to cultivate ethical behavior in others [3]. The formation of characters is intrinsic in practice in the classroom, and everyday life in classes with moral values [4]. Teachers' culture, and organizational and leadership factors influenced the ability of schools to prevent violence among their students. The social structure of the class also deals with the prevalence of bullying. Consequently, the occurrence of
Violence in school can be regarded as a result of the entire environment and does not depend solely on individual student behavior. Moral literacy is not a natural process but is acquired by an effort to develop into the true skill [5]. With a good moral understanding, the teacher is able to have a perception of the moral application in the classroom

\section{THEORETICAL}

Character education focuses on the core teaching of ethical values [6]. Berkowitz [7] said that Character Education involves the development of the necessary training and habits to live and work to improve student character. Character education helps learners to improve their academic achievement and communication skills so that they provide work to learn independently, and increase student trust. Furthermore, characterization can be successfully applied by creating a conducive learning environment, convenient for both the student itself and for others. Character education is a fundamental value obtained through one's education. Tuana [8] defines moral literacy as "a special skill and knowledge to make ethical choices in life in terms of learning skills requiring skills where an individual can be more or less competent. Moreover, Tuana [8] said that states that moral literacy is consists of three the main components are ethical sensitivity, ethical reasoning skills, and moral imagination.

Character education is an open or conscious business to influence the development of the desired quality or individual qualities [9]. Character education is an integral part of the educational effort. Character education is a system change approach to overcome the influence of students, cognition, and behavior [10]. The characters in many forms have been described as the way we express our inner and inner thoughts; the inherent value is within us, and will make some of us out of our way of expressing love, concern, integrity, respect, and all other worthy values of virtue [11]. Character education becomes an international issue, especially in developing countries. More specifically in Indonesia, character education is a major issue in 2012 until now. Lickona [12] argues that "good character consists of knowing good, wanting good, and doing good" and defining character education as deliberate attempt to develop good character based on good core goodness for the individual and good for the community 
Ethical sensitivity is a key component of moral literacy [8]. Moral sensitivity is defined as a skill to recognize how moral and decision issues in some circumstances affect the well-being of others $[13,14]$. Teachers should seriously apply the moral /character of education and then apply it to practice teaching in knowledge and understanding [15]. Character education is best done in a good environment for students to get the "true" or true habitual experience [16]. An adequate school climate has a positive effect on student psychological adjustments $[17,18]$, especially those who are at risk for academic, emotional or behavioral problems [19], and often associated with optimal health and learning development, thereby reducing maladaptive behavior [17].

\section{METHOD}

This study uses a quantitative approach. The method used in this study is a correlational method. In this research, there are three research variables: moral literacy $(\mathrm{X} 1)$, social climate (X2) and teacher perception towards character education (X3). This research uses a simple random sampling technique a sample. Population in this research is an elementary school teacher in Air Periukan, Regency Bengkulu Province. The Sample in this research amounted to 145 teachers. The instrument used to measure the three variables is Likert scale questionnaire. The hypothesis using Pearson product moment correlation technique, using an SPSS 20.

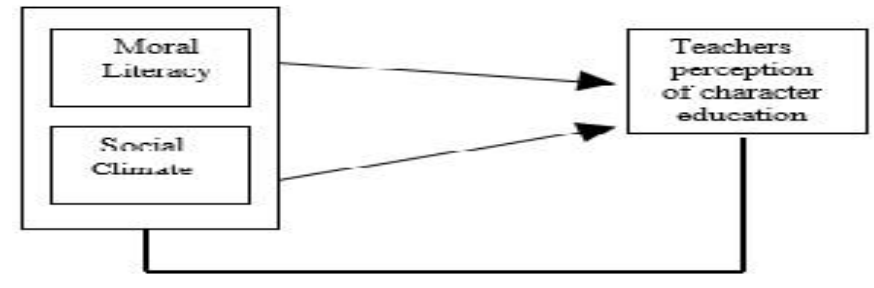

Fig. 1. Research Constellation.

\section{RESUlT AND DISCUSSION}

The hypothesis test was done to examine the influence of literacy moral (X1), social climate (X2) and teacher perception towards character education (X3). This hypothesis is tested using regression statistical test. This research shows that literacy moral (X1), social climate (X2) has relation with teacher perception toward character education (X3). The initial calculation is done using the SPSS program to determine the value of correlation between variables. The results of the calculation of the three correlations of the variables can be seen in table 1 below:

TABLE I. CORRELATION RESULTS

\begin{tabular}{|c|c|c|c|c|c|c|}
\hline & \multirow[t]{2}{*}{ Model } & \multicolumn{2}{|c|}{$\begin{array}{c}\text { Unstandardized } \\
\text { Coefficients }\end{array}$} & \multirow{2}{*}{$\begin{array}{c}\begin{array}{c}\text { Standard } \\
\text { Coefficients }\end{array} \\
\text { Beta } \\
\end{array}$} & \multirow[t]{2}{*}{$t$} & \multirow[t]{2}{*}{ Sig. } \\
\hline & & $B$ & Std. Error & & & \\
\hline \multirow{3}{*}{1} & Constant & 10,155 & 5,486 & & 1,851 &, 066 \\
\hline & $\begin{array}{l}\text { Moral } \\
\text { Literacy }\end{array}$ & ,666 & ,121 &, 622 & 5,500 &, 000 \\
\hline & \begin{tabular}{|l|} 
Social \\
Climate
\end{tabular} & ,226 &, 118 & ,216 & 1,908 &, 058 \\
\hline
\end{tabular}

From table 1, it can see that the correlation value between $\mathrm{X} 1$ to $\mathrm{Y}$ is 0.826 and $\mathrm{X} 2$ to $\mathrm{Y}$ is 0.778 which is considered strong. To know the hypotheses of each variable then it will be calculated the correlation coefficient. Based on table 1 above, the regression equation is $\mathrm{Y}=10,155+0,66 \mathrm{X} 1+0,226 \mathrm{X} 2$.

TABLE II. COEFFICIENT MORAL LITERACY (X1)

\begin{tabular}{|c|c|r|r|r|}
\hline \multicolumn{5}{|c|}{ Model Summary } \\
\hline Model & $\boldsymbol{R}$ & $\boldsymbol{R}$ Square & Adjusted $\boldsymbol{R}$ Square & $\begin{array}{c}\text { Std. Error of the } \\
\text { Estimate }\end{array}$ \\
\hline 1 &, $817^{\mathrm{a}}$ &, 668 &, 666 & 14,171 \\
\hline
\end{tabular}

From table 2, it can be seen that the coefficient R square or determinate is 0.682, which illustrates that the literary contribution of literacy (X1) and the teacher's perception of character education ( $\mathrm{Y}$ ) is $68.2 \%$. From the results of the analysis presented in the table above, obtained the price: $\mathrm{t} 1=$ 5,$500 ; \mathrm{db}=141, \mathrm{p}$-value $=0.00 / 2=0<0.05$, or Ho denied. Thus, moral literacy positively affects the perception of teachers towards character education.

TABLE III. COEFFicient Social Climate(X2)

\begin{tabular}{|c|c|c|c|c|}
\hline \multicolumn{5}{|c|}{ Model Summary } \\
\hline Model & $\boldsymbol{R}$ & $\boldsymbol{R}$ Square & $\begin{array}{c}\text { Adjusted } \boldsymbol{R} \\
\text { Square }\end{array}$ & $\begin{array}{c}\text { Std. Error of the } \\
\text { Estimate }\end{array}$ \\
\hline 1 &, $779^{\mathrm{a}}$ &, 607 &, 605 & 15,411 \\
\hline
\end{tabular}

a. Predictors: (Constant), Social_Climate_

From Table 3, it can be seen that $\mathrm{R}$ square coefficient or determinate is 0.619 , which illustrates that social contribution of social (X1) and toward teacher's perception of character education (Y) is $61.9 \%$. From the results of the analysis presented in the table above, obtained the price: $\mathrm{t} 1=1,908 ; \mathrm{db}$ $=141, \mathrm{p}$-value $=0.056 / 2=0.028<0.05$, or Ho denied. Thus, social climate positively affects the perception of teachers towards character education.

TABLE IV. COEFFICIENT XI AND X2 T Y

\begin{tabular}{|c|c|c|c|c|}
\hline \multicolumn{5}{|c|}{ Model Summary } \\
\hline Model & $R$ & R Square & $\begin{array}{c}\text { Adjusted R } \\
\text { Square }\end{array}$ & $\begin{array}{c}\text { Std. Error of the } \\
\text { Estimate }\end{array}$ \\
\hline 1 &, $822^{\mathrm{a}}$ &, 676 & 672 & 14,042 \\
\hline
\end{tabular}

From the table above, it can be seen that moral literacy and social climate have a relationship with teacher's perceptions of character education, literacy and school climate are better as well as teachers' perceptions of character education.

Based on table 1 above the coefficient of literacy moral determination (X1) and social climate (X2) to teachers' perceptions towards students $(\mathrm{Y})$ by 0,676 . This means that the contribution of $\mathrm{X} 1$ and $\mathrm{X} 2$ to $\mathrm{Y}$ is $67.6 \%$

Character education strives to cultivate good character as a real educational destination. Kim [20] argues that parents expect teachers to be a moral role model for their children. The results show that moral literacy for teachers is expected. This is because teachers are moral agents in school. Moral literacy reflects the competence to know, understand, comment and 
evaluate it playing elements in ethical decision processes, in order to make correct decisions [21].

The first hypothesis shows that moral literacy has an influence on teacher perceptions of character education. The more moral literacy the teacher will have the better the perception of character education. Perceptions of teachers in the classroom vary in student behavior, both in the same school and in the school [22]. Character education targets the child's tendency and capacity to be responsible, morally and selfmanaged [4]. Character education addressing basic human values, including moral, citizenship, behavioral politeness and socially accepted.

The second hypothesis indicates that social climate has an influence on the perception of teachers towards character education. Teachers have a role as a deliberate, accidental or accidental model, forming students' character positively or negatively. Other findings show that efficient moral education complements and enhances academic education [23]. School is one of the longest and most comprehensive contexts in shaping human development and there has been much research on school and school climate components [24,25]. The social climate in educational settings is shaped by the relationships between teachers and pupils and among pupils [26]

The third hypothesis indicates that moral literacy and social climate have an influence on teacher perceptions of character education. Social climate in schools refers to values and norms in the environment [27]. The aspect of character education is Teachers will have a good perception if understanding correctly about morality as part of character education. Teachers should be in a supportive environment to have knowledge and understanding of character education

\section{CONCLUSION}

The findings of this research can be summarized as follows:

- Moral literacy has an influence with the teacher's perception of character education. This indicates that the better the moral literacy is the better the teacher's perception of character education.

- Social climate has an influence on the perception of teachers towards character education. This shows that the better the social climate, the better the teacher's perception of character education.

- Moral literacy and school climate have an influence on teacher perceptions of character education. This shows that the better the moral of literacy and the social climate it will be better also the perception of teachers towards character education

- Character education places responsibility on teachers, parents and the community.

\section{ACKNOWLEDGEMENTS}

Acknowledgment to the head of the elementary school cluster in the Air Periukan sub district that has helped during the research process.

\section{REFERENCES}

[1] Berkowitz, M., and Bier, M., Research-based character education. The Annals of the American Academy of Political and Social Science, 591, 72-85. 2004.

[2] Bandura, A., Social cognitive theory: An agentic perspective. Annual Review of Psychology, 52(1), 1-26. 2001.

[3] Angus, T., Animals and ethics: An overview of the philosophical debate. Peterborough, ON: Broadview Press. 2003.

[4] Lapsley, D. and Yeager, D., Moral-character education. In I. Weiner, (Ed.). Handbook of psychology (Vol. 7, Educational Psychology,W. Reynolds and G. Miller, Vol. Eds.), New York: Wiley, 2013.

[5] Zdenek, B., and Schochor, D., Developing moral literacy in the classroom. Journal of Educational Administration, 45 (4), 514-53. 2007.

[6] L. Xiangdong, The Problem Of Character Education And Kohlberg's Moral Education: Critique From Dewey's Moral Deliberation. Philosophical Studies In Education Volume 45, pp 136 - 145. 2014.

[7] Berkowitz, M. W., What works in values education? International Journal of Educational Research 50(3):153-15 8. 2011.

[8] Tuana, N., Conceptualizing moral literacy. Journal of Educational Administration, 45 (4), 364-378. 2007.

[9] Hoge, J. Character education, citizenship education, and the social studies. Social Studies, 93(3), 103-108. 2002.

[10] J. Lopes, C. Oliveira, L. Reed and R. A. Gable, Character Education in Portugal, Childhood Education, 89:5, 286-289, 2013.

[11] A. Alex and K. C. Tsai, Bring Character Education Into Classroom. European Journal Of Educational Research. European Journal of Educational Research, 1(1), 163-170, 2015.

[12] Lickona, T., Education for character: How our schools can teach respect and responsibility. New York, NY: Bantam. 1991.

[13] Lovett, B. J., and Jordan, A. H., Levels of moralisation: A new conception of moral sensitivity. Journal of Moral Education, 39 (2), 175189. 2010.

[14] Mahmood, S., and Ali, B., Moral imagination and management decisionmaking: An empirical study. African Journal of Business Management, 5 (4), 1466-1480. 2011.

[15] R. Kelly and M. Bajovic, Moral Literacy Through Two Lenses: Preservice Teachers' Preparation for Character Education. International Journal of Teaching and Learning in Higher Education 2016, Volume 28, Number 1, 131-138. 2016.

[16] McClellan, B., Schools and the shaping of character: Moral education in America, 1607 present. Washington, DC: ERIC Clearinghouse of Social Studies/Social Science Education. (ERIC No. ED352310). 1992.

[17] Kuperminc, G. P., Leadbeater, B. J. and Blatt, S. J., School social climate and individual differences in vulnerability to psychopathology among middle school students. Journal of School Psychology, 39(2), 141-159. 2001.

[18] Roeser, R. W., and Eccles, J. S., Adolescents' perceptions of middle school: Relation to longitudinal changes in academic and psychological adjustment. Journal of Research on Adolescence, 8, 123-158. 1998.

[19] Haynes, N. M., Emmons, C. L., and Ben-Avie, M., School climate as a factor in student adjustment and achievement. Journal of Educational and Psychological Consultation, 8, 321-329. 1997.

[20] K. Minkang., Cultivating Teachers'Morality and the Pedagogy of Emotional Rationality.," Australian Journal of Teacher Education: Vol. 38: Iss. 1, Article 2. 2012.

[21] S. Mesut, School Management and Moral Literacy: A Conceptual Analysis of the Model. Educational Consultancy and Research Center Spring • 1425-1430, 2012.

[22] Maughan, B., Conduct disorder in context. In J. Hill and B. Maughan (Eds.), Conduct disorders in childhood and adolescent (pp. 161-201). New York: Cambridge University Press. 2001.

[23] Berkowitz, M. W., and Bier, M. C., What works in character education: A research-driven guide for practitioners. Washington, DC: Character Education Partnership. 2005. 
[24] Loukas, A., Suzuki, R., and Horton, K. D., Examining school connectedness as a mediator of school climate effects. Journal of Research on Adolescence, 16, 491-502. 2006.

[25] Khoury-Kassabri, M., Benbenishty, R., and Astor, R. A. The Effects of school climate, socioeconomics, and cultural factors on student victimization in Israel. Social Work Research, 19(3), 165-180. 2005.
[26] Allodi, M. W., The meaning of social climate of learning environments: Some reasons why we do not care enough about it. Learning Environ Res, 2010. 13:89-104

[27] Purkey, S. C., and Smith, M. S. Effective schools: A review. Elementary School Journal, 83, 427-452. 1983. 